\title{
Pattern of Serum Vitamin D in Hospitalised Patients: A Retrospective Study
}

\author{
Chhetri $N^{1}$, Chhetri $A^{2}$, Mukherjee $A^{3}$, Bhattacharya $G C^{4}, \operatorname{Sen} S^{5}$, Kumar $A^{6}$ \\ ${ }^{1}$ Dr Niru Chhetri, Associate Professor, Department of Biochemistry, MGM Medical College, Kishanganj, Bihar., \\ ${ }^{2}$ Dr Ajit Chhetri, Assistant Professor, Department of Pediatrics and Neonatology, MGM Medical College, Kishanganj, \\ Bihar. ${ }^{3}$ Dr Arati Mukherjee, Professor, Department of Biochemistry, MGM Medical College, Kishanganj, Bihar \\ ${ }^{4}$ Dr Gora Chand Bhattacharya, Professor, Department of Biochemistry, MGM Medical College, Kishanganj, Bihar \\ ${ }^{5}$ Dr Sandip Sen, Senior Consultant, Department of Internal Medicine and Cardiology, Medica North Bengal Clinic, \\ Siliguri, West Bengal, ${ }^{6}$ Dr Abhay Kumar, Associate Professor, Department of Pediatrics and Neonatology, MGM \\ Medical College, Kishanganj, Bihar, India
}

Address for Correspondence: Dr Niru Chhetri, Associate Professor, Department of Biochemistry, MGM Medical College \& Lions Seva Kendra , Kishanganj, Bihar. Email: niruchhetri@ymail.com

\begin{abstract}
Background: To find out the prevalence of vitamin D deficiency in patients hospitalised in two tertiary care centres for various ailments in Eastern Bihar and North Bengal. Methods: Hospitalised patients in MGM Medical College, Kishanganj, Bihar and Medical North Bengal Clinic, Siliguri, West Bengal (Jan 2014 to Dec 2014) who underwent blood sampling for vitamin D estimation in their work up for various ailments were included in the study. Result: Out of 108 patients, 65 were female and 43 were male in the age group ranging from 1 month to 85 years. Maximum number of patients was in the age group of 41 to 60 years. Seventy two percent patients had low vitamin D levels with $54.63 \%$ having frank deficiency and $17.59 \%$ had insufficient levels. Diabetes mellitus and/or hypertension were the most common diseases associated with hypovitaminosis D followed by diseases of respiratory system. Conclusion: Vitamin D deficiency was seen in $72 \%$ of the subjects with female preponderance. No age was spared as the age of the subjects ranged from 1 month to 85 years with majority in the 41 to 60 years age group. Among subjects with hypovitaminosis D, diabetes mellitus and /or hypertension were the most commonly encountered diseases.
\end{abstract}

Key words: Vitamin D, Hypovitaminosis D, Diabetes, Hypertension

\section{Introduction}

Vitamin D deficiency is one of the most widespread nutritional deficiencies in the world and in the Indian subcontinent despite of plenty of sunshine it prevails in epidemic proportions. As per the report of International Osteoporosis Foundation in North India, 96\% of neonates, $91 \%$ of healthy school girls, $78 \%$ of healthy hospital staff and $84 \%$ of pregnant women were found to have hypovitaminosis D [1]. Various research papers have attributed many reasons for the epidemic. Some of the important factors which contribute to the above scenario in India include socioreligious and cultural restrictions towards adequate sun exposure [2], vegetarianism [2], increased office hours in urban India

Manuscript received $25^{\text {th }}$ March 2016

Reviewed: $7^{\text {th }}$ April 2016

Author Corrected: $18^{\text {th }}$ April 2016

Accepted for Publication $28^{\text {th }}$ April 2016
[2], unplanned unspaced pregnancies [3], burqa system in Muslims [3] etc. Vitamin D whose active form is 1, 25 dihydroxy cholecalciferol is a steroid hormone. It works through specialised receptors called VDRs (vitamin D receptors) [4]. VDRs are present in almost every tissue of the body including bones, intestines, kidneys, liver, heart brain, skin, osteoblasts, activated T and B lymphocytes, gonads, prostate, breast and mononuclear cells. Hence its deficiency can involve almost any tissue in the disease process [5].

Widespread prevalence of vitamin D deficiency in India is a well known fact. This study was carried out to know the level of vitamin D in the population of this region, which has very limited data so far in this regard. 


\section{Material and Methods}

Present study is a multicentric retrospective study done in MGM Medical College, Kishanganj, Bihar and Medica North Bengal Clinic, Siliguri, West Bengal. One hundred and eight subjects were included in the study, out of which 43 patients were male and 65 were female. All indoor patients who were admitted either in MGM Medical College Kishanganj, Bihar or in Medica North Bengal Clinic, Siliguri, West Bengal and who underwent blood sampling for vitamin $\mathrm{D}$ estimation in their work up for various ailments from January 2014 to December 2014, were included in the study. The purpose of the study was to find out the status of vitamin D3 in these patients who were admitted in the hospital for various diseases. Those patients who were taking vitamin D3 or steroids in any form were excluded. Socio economic status was not a bar and patients from all socio economic status were included. The data of vitamin D assay of the above patients in the 1 year period were extracted from the hospital information system and medical record department (MRD). Only those patients whose vitamin D3 levels were estimated from the laboratories of the respective hospitals or from reputed laboratories were included in the study. The cut off levels used in our study for defining sufficiency / deficiency was based on recommendation by Michael F Holick et al [6-10], which was as follows (a) Vitamin D deficiency: Level $<20 \mathrm{ng} / \mathrm{ml}$ (b) Insufficiency: Level between 21 - 29 $\mathrm{ng} / \mathrm{ml}$ and (c) sufficient: level of $30 \mathrm{ng} / \mathrm{ml}$ and more.

\section{Results}

Hundred and eight patients were included in our study out of which 43 patients were male and 65 were female. The age group of our patients ranged from one month to 85 years.

Table 1: Age and Sex Distribution of the study population.

\begin{tabular}{|l|c|c|c|}
\hline Age group & Male (number) & Female (number) & Total (number) \\
\hline$<1$ year & 4 & 9 & 13 \\
\hline $1-20$ years & 8 & 10 & 18 \\
\hline $21-40$ years & 6 & 10 & 16 \\
\hline $41-60$ years & 9 & 23 & 32 \\
\hline $61-80$ years & 12 & 14 & 26 \\
\hline$>80$ years & 2 & 1 & 3 \\
\hline
\end{tabular}

Maximum number of patients was in the age group of $41-60$ years followed by $61-80$ years (Table 1 )

Table 2: Serum Vitamin D level in the study population $(n=108)$.

\begin{tabular}{|l|c|c|c|}
\hline Vitamin D level & Male ( percent) & Female ( percent) & Total ( percent) \\
\hline$<20 \mathrm{ng} / \mathrm{ml}$ & $21(19.44 \%)$ & $38(35.19 \%)$ & $59(54.63 \%)$ \\
\hline $21-29 \mathrm{ng} / \mathrm{ml}$ & $8(7.41 \%)$ & $11(10 \%)$ & $19(17.59 \%)$ \\
\hline$>=30 \mathrm{ng} / \mathrm{ml}$ & $15(13.89 \%)$ & $15(13.89 \%)$ & $30(27.78 \%)$ \\
\hline
\end{tabular}

As depicted in table number 2 above, out of the 108 patients vitamin D deficiency $(<20 \mathrm{ng} / \mathrm{ml})$ was seen in 59 patients whereas 19 had insufficient vitamin D levels $(21-29 \mathrm{ng} / \mathrm{ml})$ and 30 patients had normal vitamin D levels $(30 \mathrm{ng} / \mathrm{ml}$ and more). In our study $72 \%$ patients had low vitamin D levels with $54.63 \%$ having frank deficiency and $17.59 \%$ had insufficient levels. Sufficient level of vitamin D was found in $27.78 \%$.

Mean value of vitamin D in our subjects was $23.17 \mathrm{ng} / \mathrm{ml}$. Out of the 59 patients with vitamin D below $20 \mathrm{ng} / \mathrm{ml}, 21$ patients were male and 38 were female. Eight male patients and 11 female patients were found to have vitamin D levels between 21-29 ng/ml. And 15 male and 15 female patients had normal vitamin D levels. 
Histogram showing pattern of Vitamin D level in the study population $(n=108)$.

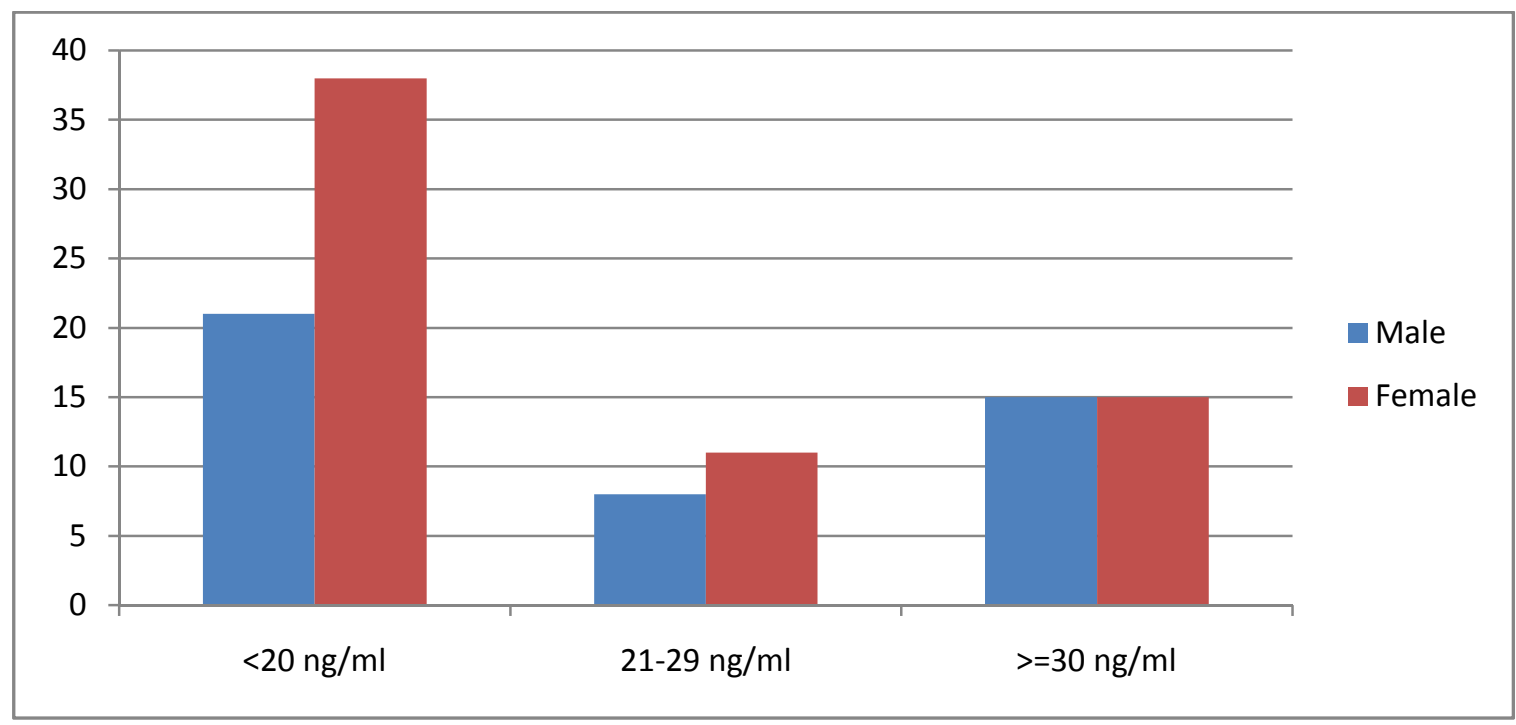

Table3: Disease pattern in Vitamin D deficient subjects, insufficiency \& sufficient Vitamin D levels patients.

\begin{tabular}{|l|c|c|c|}
\hline Diseases & $\begin{array}{c}\text { Vitamin D } \\
\text { deficient }\end{array}$ & $\begin{array}{c}\text { Vitamin D } \\
\text { insufficiency }\end{array}$ & $\begin{array}{c}\text { Sufficient } \\
\text { Vitamin D levels }\end{array}$ \\
\hline Diabetes & 8 & 1 & 1 \\
\hline Diabetes with Hypertension & 8 & 4 & 5 \\
\hline Hypertension & 7 & 4 & 6 \\
\hline Acute Respiratory Tract Infection & 9 & 3 & 0 \\
\hline Acute gastrointestinal tract infection & 3 & 1 & 0 \\
\hline Acute muscle pain & 0 & 2 & 1 \\
\hline Anaemia & 0 & 2 & 1 \\
\hline Spondylosis & 8 & 0 & 0 \\
\hline Irritable Bowel Syndrome & 0 & 0 & 0 \\
\hline Acid Peptic Disorder & 2 & 1 & 0 \\
\hline Allergic Rhinitis & 2 & 1 & 0 \\
\hline Carcinoma lung & 0 & 0 & 1 \\
\hline Fibroid uterus & 1 & 0 & 0 \\
\hline Cholelithiasis & 2 & 0 & 0 \\
\hline Fracture neck of femur & 0 & 0 & 0 \\
\hline Acute Coronary Syndrome & 1 & 0 & 0 \\
\hline COPD & 1 & 0 & \\
\hline Bronchial Asthma & 3 & 0 & \\
\hline Bronchiolitis & 4 & 0 & \\
\hline
\end{tabular}

- Twenty three patients (21.29\%) out of 108 who were vitamin D deficient (level below $20 \mathrm{ng} / \mathrm{ml}$ ) had diabetes mellitus and/or hypertension. Nineteen patients $(17.59 \%)$ had diseases related to respiratory system (Acute Respiratory Tract Infection, Allergic Rhinitis, Bronchiolitis, COPD and Bronchial Asthma) and eight patients (7.41\%) had spondylosis (Cervical / Lumbar).

- In the group having insufficient levels of vitamin D (level between 21 to $29 \mathrm{ng} / \mathrm{ml}$ ) 9 patients $(8.33 \%)$ had diabetes mellitus and /or hypertension, three $(2.77 \%)$ had respiratory tract infection. Carcinoma lung was seen in one patient.

- In patients having sufficient levels of vitamin D (30 ng/ml and more), eight patients (7.41\%) had diabetes mellitus and /or hypertension whereas anemia was seen in $6(5.55 \%)$ patients.

In the three different categories of serum vitamin D levels measured in the study population (deficient, insufficient and adequate), the patients with diabetes mellitus and diabetes mellitus with hypertension were distributed as per the table depicted below. (Table 4) 
Table 4: Vitamin D levels in diabetic subjects.

\begin{tabular}{|l|c|c|c|}
\hline Disease & Vitamin D deficiency & Vitamin D insufficiency & Adequate Vitamin D \\
\hline Diabetes & 8 & 1 & 1 \\
\hline $\begin{array}{l}\text { Diabetes and } \\
\text { Hypertension }\end{array}$ & 8 & 4 & 5 \\
\hline Total & $\mathbf{1 6}$ & $\mathbf{5}$ & $\mathbf{6}$ \\
\hline
\end{tabular}

\section{Discussion}

Vitamin D deficiency is wide spread in individuals irrespective of their age, gender, race and geography as is evident from the innumerable number of publications worldwide in this regard. Vitamin D functions in the body through both an endocrine mechanism (regulation of calcium absorption) and an autocrine mechanism (facilitation of gene expression).

The former acts through circulating calcitriol, whereas the latter, which accounts for more than $80 \%$ of the metabolic utilization of the vitamin each day, produces, uses, and degrades calcitriol exclusively intracellularly. In addition to diseases like rickets and osteoporosis the consequences of low 25(OH) D status include increased risk of various chronic diseases ranging from hypertension to diabetes to cancer [11].

There is a large body of epidemiologic data showing an inverse association between incident cancer risk and antecedently measured serum 25(OH) D [12-15]. This evidence has been accumulated for such cancers as prostate, colon, breast, lung and marrow/lymphoma, among others. Although cancer is not an uncommon entity in this part of the country, in our study only one subject had cancer. The reason could be the small sample size.

In the days when rickets was rampant, children with this disorder frequently died of respiratory infections. Calcitriol in its autocrine role has been recognized for roughly 20 years as playing a role in various aspects of the immune response [16,17]. In our study too, 16 patients $(14.81 \%)$ had Acute Respiratory Tract Infection along with low vitamin D levels (<30 ng/ml).

Both type 1 and type 2 diabetes have been associated with low vitamin D status, both current and antecedent [18-20]. The association of vitamin D status and hypertension is particularly strong. Both control trials and meta-analyses have shown a protective effect of high calcium intake for both pregnancy-related and essential hypertension [21-25]. In our study too, out of total 108 subjects, 32 patients $(30 \%)$ had diabetes mellitus and /or hypertension in association with hypovitaminosis D (<30 ng/ml). The other major group having hypovitaminosis was that with spondylosis (9\%).

\section{Conclusions}

To conclude, vitamin D deficiency was seen in $72 \%$ of our patients with a mean value of $23.17 \mathrm{ng} / \mathrm{ml}$. This problem does not spare any age group and is found in a wide spectrum of illnesses. This further reiterates the fact that hypovitaminosis $\mathrm{D}$ is a common problem in India and our region is no exception. The need of the hour is to spread awareness about the problem and evolve strategies to provide affordable vitamin D supplements and also fortify the food. The medical fraternity at large and the government can certainly bring this change, if the effort is sincere and in right earnest.

Acknowledgments: Dr P.K. Mukherjee for his constant support and guidance and Mr Subroto Paul for his help in data collection from hospital records.

Funding: Nil, Conflict of interest: None initiated. Permission from IRB: Yes

\section{References}

1. Mithal A, Wahl DA, Bonjour JP, Burckhardt P, Dawson-Hughes B, Eisman JA, et al. IOF Committee of Scientific Advisors (CSA) Nutrition Working Group. Global vitamin D status and determinants of hypovitaminosis D. Osteoporos Int 2009 Nov; 20(11): 1807-20. doi: 10.1007/s00198-009-0954-6.

2. Ritu G, Gupta A. Vitamin D deficiency in India: Prevalence, Causalities and Interventions. Nutrients. 2014 Feb; 6(2): 729-75. doi: 10.3390/nu6020729. 
3. Londhey V. Vitamin D deficiency: Indian Scenario. JAPI. 2011 Nov; 59: 695-696.

4. Holick MF. Vitamin D: A millennium perspective. J Cell Biochem. 2003 Feb 1; 88(2): 296-307.

5. MacDonald P. Molecular biology of the Vitamin D receptor. In: Holick MF (ed). Vitamin D: Physiology, Molecular biology and Clinical applications. Totowa (NJ, USA): Human Press; 1999. p. 109-28.

6. Holick MF. Vitamin D deficiency. N Engl J Med. 2007 Jul 19; 357(3): 266-81.

7. Chapuy MC, Schott AM, Garnero P, Hans D, Delmas PD, Meunier PJ. Healthy elderly French women living at home have secondary hyperparathyroidism and high bone turnover in winter. J Clin Endocrinol Metab 1996 Mar; 81(3): 1129-33.

8. Dawson-Hughes B, Heaney RP, Holick MF, Lips P, Meunier PJ, Vieth R. Estimates of optimal vitamin D status. Osteoporos Int. 2005 Jul; 16(7): 713-6 (editorial).

9. Malabanan A, Veronikis IE, Holick MF. Redefining vitamin D insufficiency. Lancet 1998 Mar 14; 351 (9105): 805-6.

10. Holick MF, Siris ES, Binkley N et al. Prevalence of vitamin D inadequacy among post menopausal North American women receiving osteoporosis therapy. J Clin Endocrinol Metab. 2005 Jun; 90(6): 3215-24.

11. Heaney Robert P. Vitamin D in health and disease. Clin J Am Soc Nephrol. 2008 Sep; 3(5): 1535-1541. doi: 10.2215/CJN.01160308.

12. Feskanich D, Ma J, Fuchs CS, Kirkner GJ, Hankinson SE, Hollis BW et al. Plasma vitamin D metabolites and risk of colorectal cancer in women. Cancer Epidemiol Biomarkers Prev. 2004 Sep; 13(9): 1501-1508.

13. Ahonen MH, Tenkanen L, Teppo L, Hakama M, Tuohimaa P. Prostate cancer risk and prediagnostic serum 25 hydroxyvitamin D levels (Finland). Cancer Causes control. 2000 Oct; 11(9): 847-852.

14. Gorham ED, Garland CF, Garland FC, Grant WM, Mohr SB, Lipkin M et al. Vitamin D and prevention of colorectal cancer. J Steroid Biochem Mol Biol. 2005 Oct; 97(1-2): 179-194.

15. Abbas S, Linseisen J, Slanger T, Kropp S, Mutschelknauss EJ, Flesch-Janys D et al. Serum 25 hydroxyvitamin D and risk of post menopausal breast cancer: Results of a large case-control study. Carcinogenesis. 2008 Jan; 29(1): 93-9.

16. Liu PT, Stenger S, Li H, Wenzel L, Tan BH, Krutzik S. Toll-like receptor triggering of a vitaminmediated human antimicrobial response. Science. 2006 Mar 24; 311(5768): 1770-1773.

17. Cantorna MT, Mahon BD: Mounting evidence for vitamin $\mathrm{D}$ as an environmental factor affecting autoimmune disease prevalence. Exp Bio Med (Maywood). 2004 Dec; 229(11): 1136-1142.

18. Scragg R, Sowers M, Bell C: Serum 25 hydroxy vitamin $\mathrm{D}$, diabetes, and ethinicity in the Third National Health and Nutrition Examination Survey. Diabetes Care. 2004 Dec; 27(12): 2813-2818.

19. Chiu KC, Chu A, Go VL, Saad MF : Hypovitaminosis D is associated with insulin resistance and beta cell dysfunction. Am J Clin Nutr. 2004 May; 79(5): 820-825.

20. Hypponen E, Laara E, Reunanen A, Jarvelin M-J, Virtanen SM. Intake of vitamin D and risk of type 1 diabetes: A birth-cohort study. Lancet. 2001 Nov 3; 358(9292): 1500-1503.

21. Forman JP, Giovanncci E, Holmes MD, BischoffFerrari HA, Tworoger SS, Willett WC et al. Plasma 25 hydroxyvitamin D levels and risk of incident hypertension. Hypertension. 2007 May; 49(5): 1063 1069.

22. Wang TJ, Pencina MJ, Booth SL, Jacques PF, Ingelsson E, Lainer K. Vitamin D deficiency and risk of cardiovascular disease. Circulation. 2008 Jan 29; 117(4): 503-511. doi: 10.1161/CIRCULATIONAHA. 107.706127.

23. Bucher HC, Guyatt GH, Cook RJ, Hatala R, Cook DJ, Lang JD. Effect of calcium supplementation on pregnancy-induced hypertension and preeclampsia. JAMA. 1996 Apr 10; 275(14): 1113-1117. doi: 10.1001 /jama.1996.03530380055031. 
24. Bucher HC, Cook RJ, Guyatt GH, Lang JD, Cook DJ, Hatala R. Effects of dietary calcium supplementation on blood pressure: A meta analysis of randomized controlled trials. JAMA. 1996 Apr 3; 275(13): 1016-1022.
25. Appel LJ, Moore TJ, Obarzanek E, Vollmer WM, Svetkey LP, Sacks FM. A clinical trial of the effects of dietary patterns on blood pressure. N Engl J Med. 1997 Apr 17; 336(16): 1117-1124.

\section{How to cite this article?}

Chhetri N, Chhetri A, Mukherjee A, Bhattacharya GC, Sen S, Kumar A. Pattern of Serum Vitamin D in Hospitalised Patients: A Retrospective Study. Int J Med Res Rev 2016;4(5):775-780.doi: 10.17511/ijmrr.2016.i05.19. 